\title{
Honoring Murat Kunt
}

\author{
A. Enis Cetin ${ }^{1,2}$
}

Published online: 29 November 2017

(c) Springer-Verlag London Ltd. 2017

This editorial of Signal, Image and Video Processing (SIViP) is dedicated to the founding editor of SIViP, Professor Murat Kunt (Fig. 1).

Prof. Kunt graduated in 1963 from Galatasaray, a legendary high school in Istanbul. He then moved to Switzerland and studied at the Swiss Federal Institute of Technology (EPFL) in Lausanne and obtained his M.S. degree in highenergy physics in 1968. He earned his Ph.D. studying facsimile image compression at the same institute. In 1974, he moved to the USA and worked as a research associate at the Massachusetts Institute of Technology (MIT). He returned to Lausanne at EPFL where he became a professor in 1980 and directed the Signal Processing Laboratory (one of the largest laboratories) of EPFL from 1989 to his retirement in 2008.

He lectured at several universities in Europe and in the world, in particular at MIT, at the University of Southern California (USC) and at University of California at Berkeley (sabbatical). His first book Traitement numérique des signaux (1980) is one of the reference books of the area and has been translated into several languages including English.

In 1978, Kunt created the first scientific journal on signal processing—entitled Signal Processing — and worked as its editor-in-chief till 2006. In parallel with the journal, he founded the European Association for Signal Processing (EURASIP). In 2006, he created the new journal Signal, Image and Video Processing and worked as its editor-in-chief till 2013.

\footnotetext{
A. Enis Cetin: On leave from Bilkent University.

$凶$ A. Enis Cetin

aecyy@uic.edu; enis4cetin@gmail.com

1 University of Illinois at Chicago, Chicago, Illinois, USA

2 Bilkent University, Ankara, Turkey
}

He served as a chairman and/or a member of the scientific committees of several international conferences and on the editorial boards of the Proceedings of the IEEE, Pattern Recognition Letters and Signal Processing. He was the cochairman of the first European Signal Processing Conference (EUSIPCO) held in Lausanne in 1980 and the general chairman of the International Conference on Image Processing (ICIP'96) held in Lausanne in 1996. He was the president of the Swiss Association for Pattern Recognition from its creation until 1997. He consults for governmental offices including the French General Assembly.

His achievements have been recognized by the awards he has received. In 1986, he became a fellow of the Institute of Electrical and Electronics Engineers (IEEE). This was followed by the gold medal of EURASIP for meritorious services in 1983, the IEEE ASSP technical achievement award in 1996, the IEEE Third millennium Medal in 2000, an honorary doctorate from the Catholic University of Leuven in 2001, the technical achievement award of EURASIP and the imaging scientist of the year award of the IS\&T and SPIE in 2003.

Several spin-offs came out of his laboratory including Alpvision, Fastcom Technologies, Visiowave, Pixartis and SpinetiX.

We would like to express our appreciation and gratitude to Prof. Murat Kunt for many years of research, mentoring, teaching and service, and to celebrate the interdisciplinary science of signal processing that has been the hallmark of his career. Here are some of the anecdotes from his former students, friends and colleagues:

"Professor Kunt is a humanist caring about people and supporting them. Professor Kunt has been an exceptional mentor to countless students and researchers who have been inspired by his knowledge, passion and enthusiasm for his 


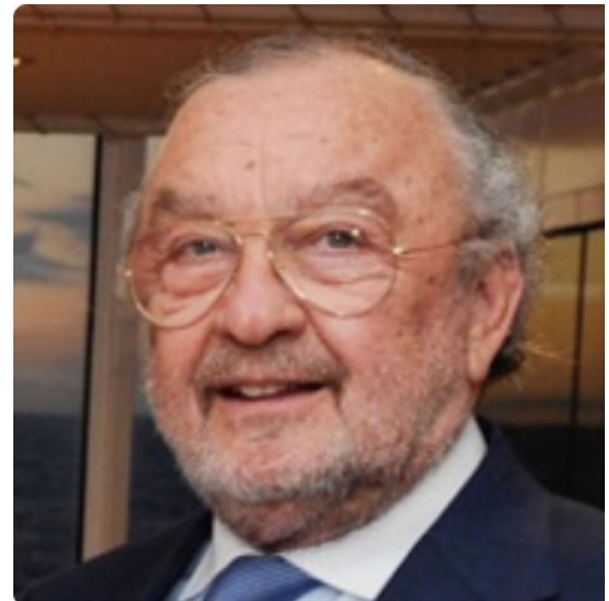

Fig. 1 Prof. Murat Kunt

field and many have now gone on to become well-respected experts in their own right.

This in itself reflects the influence and respect that Professor Kunt has commanded throughout his distinguished career. This however, did not come easily but rather was earned through his hard work and dedication to the field of signal processing." Contributed by Célia Boyer

"What did you learn today?" "Every evening, when I was leaving the lab, this was the very last utterance I was to read: it stared at me from above the exit door. At that time, I didn't fully realize the importance of asking this question to yourself each and every day. After many years, it is still the last thought that crosses my mind when I am leaving the lab. Looking back to those days I realize how fortunate I was for such stimulating forging." Contributed by Gloria Menegaz, a former student.

"I would like to also express my gratitude to Prof. Murat Kunt for his co-supervision. He has always believed in my work and trusted me. He gave me the honor to be his last PhD student, and shaped with Prof Vandergheynst the best environment to conduct my research.” By A. Alahi [1].

"Even as my career progressively tool me away from the purely scientific arena, I continued to appreciate Murat's legacy as an educator of technical and business leaders, as well as his teaching on the importance of scientific dissemination." Contributed by Roberto Castagno (former PhD student)"

"It has been a great honor to work with Murat during his career. He is a visionary scientist, and could see very early the need to develop and use intelligent algorithms reproducing some parts of the human visual system. This enabled him and his teams to achieve superior digital image processing tasks, such as image and video compression and image understanding for various applications (in medical, industrial and consumer sectors)," by Michel Benard.
"I met [Prof. Kunt] mainly during the years 2000-2008 when I was working as a journalist for the swiss daily Le Temps. What I can say is that I remember a man full of energy and humour, ambitious in the best sense of this word (for himself and for EPFL), who never had, as we say in french, "his tongue in his pocket." As a scientific, he has always been curious about the country he has adopted, its political life, and never shy to give strong advice on very different matters. Here are two stories I wrote about him in 2008 for Le Temps [2-4]." Contributed by Jean-Claude Péclet. Economie.

"At high school during an algebra exam we were sitting next to each other. We both made the same mistake quite honestly. Result: zero for both of us with the note: 'CHEATING'! Here is a picture of Murat Kunt and myself when we were students at Galatasaray." Contributed by Yavuz Isılay (Fig. 2)

"Murat has at least two passions in life: photography and cooking. At a very early age, he decided to digitalise all family photo albums and films and continued to take pictures to catalogue them all; to such an extent that when you reminisce about any past occasion, you are bound to receive a photo about the event the next day. Furthermore, when you ask a question about his recent worldwide trips, you will receive six volumes of pictures in response. Mad about pictures and pleasing friends!!!

His second hobby is cooking! The Turkish variety. To such an extent that, during the winter months, he cooks Turkish meals-imam bayildi, borek, cerkez tavuk, dolma and kofte-for the following year summer boats outings. Two years ago, at the end of winter, Electricity De France cut off his supply with the consequence of defrosting his freezer's content. What a disappointment when Murat discovered that his winter labour had gone sour and melted! Broke his heart, but undeterred, he started all over again.

What a terrific guy! Nothing is too much for his friends." Contributed by Cem Cesmig.

"In the mid 80s Murat and his assistants got invited to a local exhibition in a small town in France. We did not spend enough time to qualify this invitation and check if both the participants to the exhibition and the potential attendees were a match for our research activity. In any case, we ended up in a booth with our posters on image compression research in the middle of a local agricultural and craft show. The outcome: a lot of fun, great food and friendly conversations but little progress against our research objectives." Contributed by Michel Benard.

Prof. Kunt's latest book is non-technical. It is about his father [4]. Here is Prof. Ali Akansu's review:

"Murat (Kunt) nailed it again. It is a fantastic book. Congratulations!"

"I read this book [5] over a weekend and found myself deeply immersed into about a century of a unique family history. There are several great messages this book is delivering: 


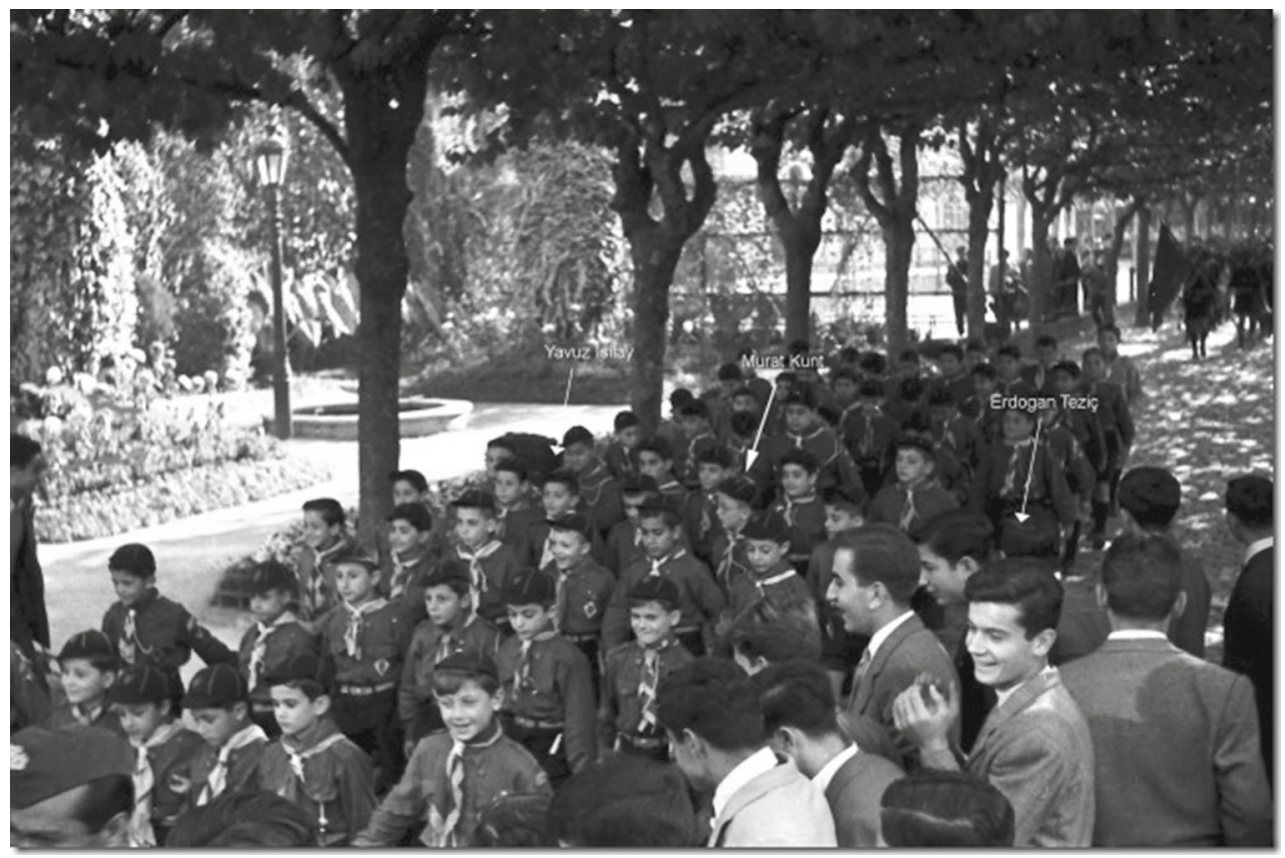

Fig. 2 Murat Kunt and Yavuz Isılay at Galatasaray Lisesi, Istanbul, Turkey in 1950s

- first and most, a son's love for his father is unique and precious,

- cultivating family values over a lifetime is a fabulous asset,

- life is full of unexpected events and a rich and fulfilling family life remains a critical success factor, whatever the issues are.

In addition to these very human and universal messages, the text includes plenty of funny anecdotes, interesting travels back in time in Turkey, Germany and Switzerland, and a lot of interesting cultural information.

The style of the author is the result of cooking together his very professional, scientific and factual reporting, his ability to share emotions and last but not least his great sense of humor.

In today's time a book like this one is a lighthouse." Contributed by Michel Benard.

"This [book] is a most moving and affecting tribute to a wise and caring father crafted by his son. Adnan's childhood in pre-WWII Turkey is effectively narrated, and the writer's entertaining and evocative recount of his father's childhood experiences and his education detailed and engaging, especially his tertiary studies in WWII Berlin. Adnan became a noted entrepreneur and innovator in postwar Turkey, and an aspirational and much admired citizen within Turkish society in his day. Sentimental but never soppy; intimate but never intrusive; greatly respectful but always gently realistic, this book is written with great integrity, candour and frankness, offering authentic insights into wise and effective parenting that the author himself hopes will influence other fathers to reflect thoughtfully on the manner of their fathering." Contributed by Roderic Kefford.

"Prof. Kunt is one of the best persons I have ever met in my career." Contributed by Fulvio Moschetti.

The article by Roberto Castagno eloquently describes the research and teaching principles of Prof. Kunt [6].

As SIViP rolls the 10-year mark, Prof. Kunt's legacy is here to stay. The journal receives over 800 manuscripts every year and the current acceptance rate is about $20 \%$.

\section{References}

1. Alahi, A.: Vision-Based Scene Understanding with Sparsity Promoting Priors, Thèse No. 5070. Ph.D. Thesis, EPFL (2011)

2. Péclet, J.-C.: L'EPFL Salue la Riche Carrière de Murat Kunt, Le Temps, Switzerland, 08/29/2008. https://www.letemps.ch/ economie/2008/08/29/epfl-salue-riche-carriere-murat-kunt

3. Péclet, J.-C.: Provocateur, Le Temps, 29 Aug 2008, Switzerland. https://www.letemps.ch/node/405769

4. Péclet, J.-C.: L'homme du Jour, Murat Kunt, le Compresseur, Le Temps, 08/29/2008, Switzerland. https://www.letemps.ch/2008/08/ 29/homme-jour-murat-kunt-compresseur

5. Kunt, M.: Adnan the Father. Dorrance Publishing, Pittsburg (2017)

6. Castagno, R.: Savoir Faire et Faire Savoir: what I learned about innovation while I thought I was doing a $\mathrm{PhD}$. Signal Image Video Process. (2017). https://doi.org/10.1007/s11760-017-1210-8 (in this issue) 